\title{
Long term radiological effects of short term exposure to amosite asbestos among factory workers
}

\author{
Rodney Ehrlich, Ruth Lilis, Eva Chan, William J Nicholson, Irving J Selikoff
}

\begin{abstract}
Chest radiographs were read from a subcohort of 386 factory workers with short term exposure to amosite asbestos (median exposure six months) and long follow up (median 25 years). Prevalence of abnormality was determined independently by two readers from the first film available after 20 years from first employment. Serial films were obtainable for 238 men (median interval from first to last film: nine years). Progression was classified with a direct progression scoring scale. Individual dust exposure estimates were derived from dust counts from two similar plants. With as little as one month or less of employment, about $20 \%$ of the films showed parenchymal abnormality and about a third showed pleural abnormality. Those in the lowest cumulative exposure stratum $(<5$ fibreyears $/ \mathrm{ml}$ ) were similarly found to have high rates of abnormality. Dose-response relations were present in the data of both readers. Smokers had higher rates of parenchymal abnormality. On multivariate analysis, cumulative exposure was the exposure variable most closely related to parenchymal abnormality, and time from first employment was the variable most closely related to pleural abnormality. Progression (including first attacks) 20 or more years after ceasing employment occurred and was more common for pleural than for parenchymal abnormality. It is concluded that with exposure to high concentrations of amosite such as existed in this factory and with follow up for at least 20 years, (1) exposure for as little as a month was sufficient to produce radiological signs of parenchymal and pleural fibrosis, (2) no cumulative exposure threshold for parenchymal and pleural fibrosis was detectable, and (3) parenchymal and pleural progression were still detectable $\geqslant 20$ years after the end of exposure.
\end{abstract}

Division of Environmental and Occupational Medicine, Department of Community Medicine, Mount Sinai Medical Centre, New York, NY, USA R Ehrlich, R Lilis, E Chan, W J Nicholson, I J Selikoff
Few studies of workforces exposed to asbestos have focused on short term workers. Most groups have been studied in cross section and have had high average durations of exposure. In these studies the average worker had typically accumulated 15 or 20 years of employment. In determining the fate of workers with short term exposure (of the order of months or a few years), follow up needs to be of sufficient duration to exceed the period of latency for the effect of interest.

This study made use of the availability of a cohort of amosite asbestos factory workers with heavy short term exposure and long follow up. The objective was to determine the long term radiological outcome in these workers. Particular interest centred on those with less than one year of exposure and with low cumulative exposure ( $<25$ fibre-years $/ \mathrm{ml}$ ) to asbestos fibre.

The availability of serial $x$ ray films also made it possible to investigate "late" radiological progression, that is, progression between films taken 20 years and more after exposure had ceased.

\section{Population}

From 1941 to the end of 1954 a plant in Paterson, New Jersey, manufactured asbestos insulation material for use in ships and in industry. Because of wartime conditions there was a high turnover of men, many of whom worked for less than a year. Between June 1941 and December 1945, 933 men entered employment. Epidemiological surveillance started in 1961 and the cohort has been followed up to the present. ${ }^{1-3}$ The mortality experience of 820 of these men (those alive five years after starting employment) has been analysed from that point to the end of December $1982 .{ }^{2}$ A significantly increased all cause mortality (standardised mortality ratio $(S M R)=$ 167) and lung cancer mortality (SMR $=541)$ were found when compared with the white male population of New Jersey. Using the best evidence available to classify deaths, we found 111 deaths from lung cancer, 17 from mesothelioma, and 31 from asbestosis. ${ }^{2}$ An excess of lung cancer was evident in that stratum of workers with as little as a month or less of exposure. $^{2}$

The first group of workers to be studied in this plant were enrolled in 1954 and described in 1961. ${ }^{4}$ 
Only 17 men were in this initial study and the first extensive radiographic survey to which surviving men were invited was undertaken in 1968. There were subsequent surveys, the last being in 1984. A further group of $x$ ray films was obtained from other hospitals and physicians. A total of 414 cohort members had one or more posteroanterior chest radiographs available. Of these, 28 reported exposure to asbestos in other occupations. This left 386 men $(41 \%$ of the original cohort) with occupational exposure to asbestos only at the Paterson plant. This group was the object of this study.

\section{EXPOSURE}

The duration of employment, age at entry, and job title of each man were available from plant records and from interviews at the time of medical examinations. Average fibre counts for each job title were estimated from measurements carried out at two other plants operated by the company after 1954; one in Tyler, Texas and another in Port Allegheny, Pennsylvania. Much of the equipment from the Paterson plant was used in the Tyler plant and all of the plants employed similar materials and equipment to produce similar products. All were, by historical accounts, very dusty. Exhaust ventilation in one of the later plants was inferior to that at Paterson, and in the other, superior. Dust counts using modern fibre counting methods (membrane filter method) were carried out at these plants by the National Institute for Occupational Safety and Health (NIOSH) in 1968 and 1971. These fibre counts were supplemented by data collected at the Tyler plant in 1969 by an industrial hygiene consultant. Counts in the two plants were similar for the same job.

The estimated counts ranged from 5 fibres $/ \mathrm{ml}$ (> $5 \mu \mathrm{m}$ in length) among office workers, to $120 \mathrm{fibres} / \mathrm{ml}$ among disintegrator operators. Using information on job title and duration of service for each subject at the Paterson plant, the fibre count estimates were used to derive the average fibre concentration and cumulative exposure for each subject.

As well as occupational exposure, the Paterson workers had exposure to asbestos fibre in their homes from contamination of the domestic environment by asbestos brought home on their clothing. The effect of such residential exposure has been determined from a study of the household contacts of these workers, among whom high rates of radiological abnormality as well as some mesotheliomas have been found. ${ }^{5}$

Almost all of the asbestos used in the factory was amosite imported from a single amosite mine in South Africa. Small amounts of chrysotile were used at one time.

The average age of first employment of the study group was 31 , higher than usual for entry into a new line of work because of the wartime shortage of labour. Information on lifetime smoking state during the first 20 years after entry to employment was available for $98 \%$ of the study group. Employment and smoking histories of some men were updated when they attended surveillance examinations.

\section{Methods}

The $x$ ray films were read in two stages; the first for prevalence of abnormality, the second for prevalence of progression. Readings were carried out independently by two of us (RL and RIE), certified as B readers by NIOSH.

In the first stage the first available film of each man was extracted. In only 53 cases had the first film been taken less than 20 years from the start of employment. In 22 of these, at least one other film was available postdating 20 years from first exposure. These 22 films were also extracted for independent reading. This was done to maximise the number of cases 20 or more years from first employment that would be available for analysis.

All of these films were read in random order by each reader. The readers were aware that study films were from an asbestos exposed population but had no further information on any individual film. Each film was classified according to the 1980 International Labour Organisation International Classification of Radiographs of Pneumoconioses (ILO scale).

For purposes of reading progression, all of the unmasked films on each subject were read side by side in known temporal sequence. Each film was classified, in chronological order, according to the ILO scale. A single summary judgment about the presence or absence of progression or regression was made for each series of films according to the following scale: 2 $=$ probable or definite progression, $1=$ possible progression, $0=$ no change, $-1=$ possible regression, $-2=$ probable or definite regression. This judgment was made separately for parenchymal and pleural changes. Parenchymal progression included first appearance ("attacks") or an increase in irregular opacities in extent or profusion. Pleural progression included attacks or extension of pleural thickening or calcification.

\section{ANALYSIS}

For univariate analysis, small parenchymal opacities were classified into three ILO major profusion categories: 0,1 , or 2 and 3 combined. The shape of parenchymal opacities was also taken into account. Only readings of irregular opacities or mixed irregular and rounded opacities were included.

For multivariate analysis, "any abnormality" was defined as a reading of $1 / 0$ or greater, that is, major ILO categories 1, 2, and 3 were combined.

Pleural abnormality, for both univariate and multivariate analysis, was defined as any pleural 
thickening of the chest wall or diaphragm. Costophrenic angle blunting without any other pleural abnormality was excluded from this definition because of its insufficient specificity for the effects of asbestos.

The evaluations of each reader were analysed independently. Agreement between readers beyond what would be expected by chance was expressed as a kappa statistic. ${ }^{6}$ Two way tables of outcome by each independent variable of interest were examined. Class intervals of duration of exposure and cumulative exposure were chosen to balance numbers in each interval and to be epidemiologically meaningful. The simultaneous influence of a number of independent variables were examined in a logistic regression model using the statistical software of BMDP via SAS (SAS Institute Inc, release 5.18, March 1989).

Progression of pleural and parenchymal abnormalities were analysed separately. To determine the frequency of "late" progression, only film series starting 20 or more years after exposure had ceased were included. To analyse the determinants of progression it was necessary to control for variation in both the number of films available for each man and the interval between first and last film. To do this we entered these two variables into the logistic model.

\section{Results}

Compared with the rest of the cohort, the study group was younger at entry to employment and had a higher proportion of men alive by 1988 (table 1). The study group had a higher mean duration of employment and higher mean average exposure to dust that resulted in a greater cumulative exposure. Information on smoking was available for a much higher proportion of the study group. Among those men with information on smoking available, however, smoking habits were comparable between the two groups. Fifteen per cent of the study group had never smoked.

Among the 238 subjects with serial films, the median interval from first employment to the first film was $26 \cdot 5$ (range 3-42) years, and to the last film 35 (range 8-45) years. The median interval between the first and last film was nine (range 2-25) years and the median number of films was three (range 2-10).

\section{PREVALENCE OF ABNORMALITY ON FIRST FILM}

The two readers agreed on the presence or absence of parenchymal abnormality ( $\geqslant 1 / 0$ on ILO scale) in 281 out of 370 films $(76 \%)$ judged readable by both. Table 2 gives an array of respective readings of the same films. The kappa statistic was $0 \cdot 47$, an indication of moderate agreement beyond chance. For pleural abnormality, there was concurrence on 290 out of 370 films $(78 \%)$, giving a kappa statistic of $0 \cdot 56$, similarly indicating moderate agreement beyond chance.

\section{PARENCHYMAL ABNORMALITY}

Even among the workers with exposures of a month or less a significant proportion with parenchymal abnormality on films taken 20 or more years from onset of employment was found (25\% according to reader 1 , and $19 \%$ according to reader 2 ) (table 3 ). A duration-response relation was evident for both readers, although the pattern differed. In particular, for reader 1 , the prevalence of abnormality was constant at about $25 \%$ for men in the three groups with less than a year's duration of employment, with a sharp increase after a year. The duration-response relation for reader 2 was somewhat steeper, with an increasing rate of abnormality evident even across the groups that had worked for less than a year.

When the relation of parenchymal abnormality to cumulative exposure was analysed (table 3 ), the group with the lowest cumulative exposure $(\leqslant 5$ fibre-years $/ \mathrm{ml}$ ) showed a significant rate of abnormality ( $23 \%$ according to reader 1 , and $17 \%$ according to reader 2 ). The prevalence of abnormality increased with increasing cumulative exposure for both readers.

To remove the influence of films adjudged abnormal by one reader but not by the other, we redefined an abnormal film as one read into the ILO scale as $1 / 0$ or greater by both readers. Table 4 displays the abnormality thus defined in relation to duration and cumulative exposure. Whereas the prevalence of

Table 1 Comparison of study group with rest of cohort

\begin{tabular}{|c|c|c|}
\hline & Study group $(n=386)$ & Rest of cohort $(n=547)$ \\
\hline $\begin{array}{l}\text { No alive in } 1988 \\
\text { Age at first employment }(\mathrm{y}) \dagger \\
\text { Age at first film (y) } \dagger \\
\text { Interval from first employment to first film }(\mathrm{y}) \ddagger \\
\text { Exposure concentration (fibres } / \mathrm{ml}) \dagger \\
\text { Duration of employment }(\mathrm{y}) \ddagger \\
\text { Cumulative exposure (fibre-years } / \mathrm{ml}) \ddagger \\
\text { Smoking information available } \\
\text { Never smoked }\end{array}$ & $\begin{array}{l}103(27 \%) \\
31(11) \\
58(11) \\
25(3-42) \\
51 \cdot 8(25) \\
0 \cdot 50(0 \cdot 01-13) \\
25 \cdot 1(0 \cdot 1-720) \\
98 \% \\
15 \%\end{array}$ & $\begin{array}{l}60(11 \%)^{\star} \\
41(14)^{\star \star} \\
- \\
- \\
44 \cdot 4(18)^{\star \star} \\
0 \cdot 42(0 \cdot 01-13) \\
13 \cdot 8(0 \cdot 4-720) \\
62 \% \star \star \\
7 \% \star\end{array}$ \\
\hline
\end{tabular}

${ }^{\star} \mathrm{p}<0.05 ;{ }^{\star \star} \mathrm{p}<0.0001$.

$+\mathrm{M} \operatorname{san}(\mathrm{SD})$.

$\ddagger$ Median (range). 
Table 2 Interreader agreement on parenchymal abnormality

\begin{tabular}{|c|c|c|c|c|c|c|}
\hline & \multicolumn{6}{|c|}{ Reader 2} \\
\hline & \multicolumn{6}{|c|}{ Profusion * } \\
\hline & $0 / 0,0 / 1$ & $1 / 0$ & $1 / 1,1 / 2$ & 2 & 3 & Total \\
\hline $\begin{array}{c}\text { Reader } 1: \\
0 / 0,0 / 1 \\
1 / 0 \\
1 / 1,1 / 2 \\
2 \\
3 \\
\text { Total }\end{array}$ & $\begin{array}{r}195 \\
17 \\
15 \\
4 \\
0 \\
231\end{array}$ & $\begin{array}{r}22 \\
3 \\
7 \\
1 \\
0 \\
33\end{array}$ & $\begin{array}{r}24 \\
16 \\
14 \\
10 \\
2 \\
66\end{array}$ & $\begin{array}{r}5 \\
0 \\
8 \\
13 \\
4 \\
30\end{array}$ & $\begin{array}{r}2 \\
0 \\
1 \\
3 \\
4 \\
10\end{array}$ & $\begin{array}{c}248 \\
36 \\
45 \\
31 \\
10 \\
370 \dagger\end{array}$ \\
\hline
\end{tabular}

«ILO scale.

tNumber judged readable by both readers out of 386 (first available) films.

abnormality in each group was reduced compared with the findings of the individual readers, the doseresponse relation was preserved. Furthermore, the prevalence in the lowest stratum of both duration of employment and cumulative exposure remained at over $10 \%$.

The influence of smoking state was explored by a comparison of the rates of abnormality among men with any smoking history (current, ex-smokers, or pipe smokers) with those of men who had never smoked, at different levels of cumulative exposure (table 5). Smokers had a higher prevalence of parenchymal abnormality at all levels of cumulative exposure for reader 1 and for three of the four exposure groups for reader 2 . Overall, the ratio of abnormality among smokers to that of non-smokers was 1.34 for reader 1 and 1.25 for reader 2 .

In the multivariate analysis, the following variables were entered into a backward stepwise logistic regression model: average dust concentration, duration of employment, cumulative exposure, age at timeoffilm, interval fromfirstemployment to firstfilm, and smoking state. In this analysis the first film of each subject was used irrespective of whether it was dated before 20 years from onset or after. Of the variables entered, cumulative exposure showed the closest independent relation to parenchymal abnormality in the model. Also, for reader 2, age at time of film entered the model.

For purposes of estimation, four independent variables were inserted in the final model: cumulative exposure, time from first employment, age at film, and smoking state. Table 6 presents estimates of the odds ratio, $95 \%$ confidence intervals, and $p$ value of each variable found to be statistically significant (smoking state, although not a significant predictor of parenchymal abnormality, is included as well). The relative risk of developing small parenchymal opacities (expressed as the odds ratio) for an increment in cumulative exposure of 10 fibre-years $/ \mathrm{ml}$ was 1.06 to 1.07 , depending on reader. This implies an increase in the risk of parenchymal abnormality of $6 \%$ to $7 \%$ for every 10 fibre-years $/ \mathrm{ml}$ increase in cumulative exposure.

\section{PLEURAL ABNORMALITY}

High rates of pleural abnormality were detected by both readers (table 7). Even with a month or less of employment, over a third (35\% reader 1 and $38 \%$ reader 2) of the group showed some pleural abnormality. No duration-response relation could be detected.

When pleural abnormality was examined in relation to cumulative exposure (table 5), high rates of pleural abnormality occurred even in the lowest stratum ( $<5$ fibre-years $/ \mathrm{ml}$ ) of exposure $(38 \%$ both readers). The rates showed no clear trend with increasing cumulative exposure. When pleural abnormality was examined by smoking state, the rates of smokers were no higher than those of nonsmokers.

The only exposure variable that could be shown on univariate analysis to influence the rate of pleural abnormality was time from first employment (table

Table 3 Parenchymal abnormality by reader, duration of employment, and cumulative exposure $\geqslant 20$ years after first employment $(n=355 \dagger)$

\begin{tabular}{|c|c|c|c|c|c|c|c|}
\hline & \multirow[b]{2}{*}{ Not } & \multicolumn{3}{|c|}{ Profusion $\star($ reader $1 ; n=347)$} & \multicolumn{3}{|c|}{ Profusion $\star($ reader $2 ; n=344)$} \\
\hline & & $O(\mathrm{No}(\%))$ & $1(\mathrm{No}(\%))$ & $\geqslant 2(\mathrm{No}(\%))$ & $O(N o(\%))$ & $1(\mathrm{No}(\%))$ & $\geqslant 2(\mathrm{No}(\%))$ \\
\hline $\begin{array}{l}\text { Duration (m } \\
\leqslant 1 \\
1 \cdot 01-6 \\
6 \cdot 01-12 \\
12 \cdot 01-24 \\
>24\end{array}$ & $\begin{array}{r}75 \\
75 \\
110 \\
49 \\
63 \\
58\end{array}$ & $\begin{array}{l}56(75) \\
79(76) \\
36(75) \\
39(62) \\
21(37)\end{array}$ & $\begin{array}{r}19(25) \\
21(20) \\
9(19) \\
17(27) \\
14(25)\end{array}$ & $\begin{array}{l}0 \\
4(4) \\
3(6) \\
7(11) \\
22(39)\end{array}$ & $\begin{array}{l}59(81) \\
74(69) \\
27(61) \\
36(58) \\
18(32)\end{array}$ & $\begin{array}{l}13(18) \\
31(29) \\
12(27) \\
21(34) \\
15(26)\end{array}$ & $\begin{array}{c}1(1) \\
3(3) \\
5(11) \\
5(8) \\
24(42)\end{array}$ \\
\hline $\begin{array}{c}\text { Cumulative } \\
\leqslant 5 \\
5 \cdot 1-25 \\
25 \cdot 1-125 \\
>125\end{array}$ & $\begin{array}{c}\text { ure (fit } \\
91 \\
102 \\
131 \\
62\end{array}$ & $\begin{array}{c}\text { rs/ml): } \\
66(76) \\
66(74) \\
81(67) \\
18(36)\end{array}$ & $\begin{array}{l}21(24) \\
21(24) \\
26(21) \\
12(24)\end{array}$ & $\begin{array}{c}0 \\
2(2) \\
14(12) \\
20(40)\end{array}$ & $\begin{array}{l}71(83) \\
60(67) \\
68(57) \\
15(31)\end{array}$ & $\begin{array}{l}14(16) \\
25(28) \\
42(35) \\
11(22)\end{array}$ & $\begin{array}{c}1(1) \\
4(4) \\
10(8) \\
23(47)\end{array}$ \\
\hline
\end{tabular}

$\star$ ILO scale.

tNumber of films available; exceeds reader totals by number of films judged unreadable. 
Table 4 Parenchymal abnormality (profusion $\geqslant 1 / 0$ read by both readers) by duration of employment and cumulative exposure, $\geqslant 20$ years from first employment.

\begin{tabular}{|c|c|c|}
\hline & No $(n=340)^{\star}$ & Abnormal (No (\%)) \\
\hline $\begin{array}{l}\text { Duration (m } \\
\leqslant 1 \\
1 \cdot 01-6 \\
6 \cdot 01-12 \\
12 \cdot 01-24 \\
-24\end{array}$ & $\begin{array}{r}73 \\
104 \\
43 \\
62 \\
58\end{array}$ & $\begin{array}{r}8(11) \\
16(15) \\
9(21) \\
16(26) \\
32(55)\end{array}$ \\
\hline $\begin{array}{l}\text { Cumulative } \\
\leqslant 5 \\
5 \cdot 1-25 \\
25 \cdot 1-125 \\
>125\end{array}$ & $\begin{array}{l}\text { (fibre-years } / \mathrm{ml} \text { ): } \\
85 \\
87 \\
119 \\
49\end{array}$ & $\begin{array}{l}10(12) \\
12(14) \\
30(25) \\
29(59)\end{array}$ \\
\hline
\end{tabular}

^Number judged readable by both readers out of a possible 355 .

Table 5 Parenchymal abnormality (profusion $\geqslant 1 / 0$ ) by smoking state, cumulative exposure, and reader, $\geqslant 20$ years from first employment

\begin{tabular}{|c|c|c|c|c|}
\hline & & $\mathrm{No}^{\star}$ & $\begin{array}{l}\text { Reader } 1 \\
(\text { No }(\%) \dagger\end{array}$ & $\begin{array}{l}\text { Reader } 2 \\
(\mathrm{No}(\%))^{\dagger}\end{array}$ \\
\hline \multicolumn{5}{|c|}{ Cumulative exposure (fibre-years $/ \mathrm{ml}$ ): } \\
\hline \multirow[t]{2}{*}{$\leqslant 5$} & $\mathrm{~s}$ & 75 & $19(26)$ & $14(19)$ \\
\hline & Ns & 13 & $2(15)$ & $1(7)$ \\
\hline \multirow[t]{2}{*}{$5 \cdot 1-25$} & $\mathrm{~S}$ & 79 & $21(28)$ & $26(35)$ \\
\hline & Ns & 11 & $2(18)$ & $2(18)$ \\
\hline \multirow[t]{2}{*}{$25 \cdot 1-125$} & $\mathrm{~S}$ & 105 & $36(35)$ & $48(47)$ \\
\hline & Ns & 17 & $4(22)$ & $4(22)$ \\
\hline \multirow[t]{2}{*}{$>125$} & $\mathrm{~S}$ & 39 & $26(66)$ & $24(65)$ \\
\hline & Ns & 12 & $6(55)$ & $10(83)$ \\
\hline \multirow[t]{2}{*}{ Total } & $\mathrm{S}$ & 298 & $102(35)$ & $112(39)$ \\
\hline & Ns & 53 & $14(26)$ & $17(31)$ \\
\hline
\end{tabular}

*Total films available for reading with smoking state known $(\mathrm{n}=351)$.

Percentages calculated on the number of films in each category judged readable by that reader.

$\mathrm{S}=\mathrm{Smoker} ; \mathrm{Ns}=$ non-smoker

Table 6 Selected predictors of parenchymal and pleural abnormality in logistic regression analysis, ${ }^{\star}$ by reader $(n=386)^{\dagger}$

\begin{tabular}{|c|c|c|}
\hline Variable & Odds ratio $95 \% \mathrm{CI}$ & p Value \\
\hline \multicolumn{3}{|c|}{ Reader 1} \\
\hline \multicolumn{3}{|l|}{ Parenchymal abnormality: } \\
\hline $\begin{array}{l}\text { Cumulative exposure } \\
(10 \text { fibre-years } \mathrm{ml})\end{array}$ & $1.06(1.04-1.09)$ & 0.000 \\
\hline Age at time of film (decade) & $1.18(0.96-1.46)$ & $0 \cdot 11$ \\
\hline Smoking state & $1.62(0.81-3.23)$ & $0 \cdot 16$ \\
\hline \multicolumn{3}{|l|}{ Pleural abnormality: } \\
\hline $\begin{array}{l}\text { Time from first employment } \\
\text { (decade) }\end{array}$ & $1 \cdot 67(1 \cdot 15-2 \cdot 42)$ & 0.007 \\
\hline \multicolumn{3}{|c|}{ Reader 2} \\
\hline \multicolumn{3}{|l|}{ Parenchymal abnormality: } \\
\hline (10 fibre-years $\mathrm{ml}$ ) & $1.07(1.04-1 \cdot 10)$ & 0.000 \\
\hline Age at time of film (decade) & $1.31(1.05-1.62)$ & $0 \cdot 01$ \\
\hline Smoking state & $1.58(0.81-3.07)$ & $0 \cdot 19$ \\
\hline \multicolumn{3}{|l|}{ Pleural abnormality: } \\
\hline $\begin{array}{l}\text { Time from first employment } \\
\text { (decade) }\end{array}$ & $1.85(1 \cdot 24-2 \cdot 76)$ & 0.002 \\
\hline
\end{tabular}

*Independent variables in each model were cumulative exposure, age at time of film, smoking state, and time from first employment. First film of each subject included irrespective of whether or not 20 years had elapsed since first employment.
8). This was confirmed in logistic regression analysis, using the same variables as for parenchymal abnormality (table 6). Time from first employment showed the closest independent relation to pleural abnormality, with estimated odds ratios (for 10 year increments) of 1.67 to 1.85 depending on the reader. This implies an increase in the risk of pleural abnormality of 67 to $85 \%$ for every decade that elapses from first exposure. Cumulative exposure, age at film, and smoking state did not improve the prediction of pleural abnormality in the model.

\section{PROGRESSION}

Cases with "probable or definite progression" were taken as progressors. As there were few cases read with regression, these were combined with those showing "no progression" and "possible progression" as non-progressors.

The readers agreed on the presence or absence of progression of parenchymal abnormality in 197 out of 232 cases $(85 \%)$; the kappa statistic was 0.50 (moderate agreement beyond chance). Agreement was slightly less regarding pleural progression, with accord on the classification of 171 out of 232 cases $(73 \%)$, which gave a kappa statistic of 0.47 .

Reader 1 was more likely to detect progression (table 9), classifying 44 cases $(21 \%$ of those with serial films) as showing parenchymal advance. Of these, 21 were attacks. Reader 2 identified 29 cases ( $14 \%$ of cases with serial films) with progression, of which nine were attacks.

In multivariate analysis, in which the influence of cumulative exposure, age and smoking state on parenchymal progression was simultaneously analysed, the variable showing the closest independent association with parenchymal progression was cumulative exposure. This association was statistically significant for reader $2(p=0.03)$ but not quite for reader $1(p=0.07)$. None of the other variables were significant.

For progression of pleural abnormality, reader 1 was again more likely to classify change, identifying 107 cases ( $50 \%$ of cases with serial films), of which 44 were attacks. Reader 2 appraised 77 cases $(36 \%)$ as showing pleural progression, of which 31 were attacks.

In multivariate analysis, the interval from first employment to the first film showed a significant association with pleural progression for reader 1 . None of the independent variables tested were related to risk of pleural progression for reader 2 .

\section{Discussion}

The high rates of radiological abnormality reported here reflect the dust concentrations prevailing in this plant in the 1940s and early 1950s; these were high, as reconstructed. What makes this workforce unusual is that the dose of asbestos was accumulated rapidly, 
Table 7 Pleural abnormality by reader, duration of employment and cumulative exposure, $\geqslant 20$ years from first employment ( $n=355$,

\begin{tabular}{|c|c|c|c|c|}
\hline & \multicolumn{2}{|c|}{ Reader $1(n=347)$} & \multicolumn{2}{|c|}{ Reader $2(n=344)$} \\
\hline & $\begin{array}{l}\text { No abnormality } \\
(\text { No }(\%))\end{array}$ & $\begin{array}{l}\text { Abnormality } \\
(\text { No }(\%))\end{array}$ & $\begin{array}{l}\text { No abnormality } \\
(\text { No }(\%))\end{array}$ & $\begin{array}{l}\text { Abnormality } \\
(\text { No }(\%))\end{array}$ \\
\hline $\begin{array}{c}\text { Duration } \\
<1 \\
1-\leqslant 6 \\
6-<12 \\
12-\leqslant 24 \\
>24\end{array}$ & $\begin{array}{l}49(65) \\
47(45) \\
28(58) \\
24(38) \\
31(54)\end{array}$ & $\begin{array}{l}26(35) \\
57(56) \\
20(42) \\
39(62) \\
26(46)\end{array}$ & $\begin{array}{l}46(62) \\
59(55) \\
26(59) \\
28(45) \\
33(58)\end{array}$ & $\begin{array}{l}28(38) \\
49(45) \\
18(41) \\
34(55) \\
24(42)\end{array}$ \\
\hline $\begin{array}{l}\text { Cumulative } \\
<5 \\
5-\leqslant 25 \\
25-\leqslant 125 \\
>125\end{array}$ & $\begin{array}{l}\mathrm{ml}): \\
55(63) \\
45(51) \\
54(45) \\
22(50)\end{array}$ & $\begin{array}{l}32(37) \\
44(49) \\
67(55) \\
25(50)\end{array}$ & $\begin{array}{l}54(63) \\
51(57) \\
58(48) \\
28(57)\end{array}$ & $\begin{array}{l}32(37) \\
38(43) \\
62(52) \\
21(43)\end{array}$ \\
\hline
\end{tabular}

Table 8 Pleural abnormality by reader and time from first employment $(n=386)$ *

\begin{tabular}{|c|c|c|c|c|c|}
\hline & \multirow[b]{2}{*}{$N o^{\star}$} & \multicolumn{2}{|c|}{ Reader 1 ( $n=381)^{\dagger}$} & \multicolumn{2}{|c|}{ Reader $2 / n=373) \dagger$} \\
\hline & & $\begin{array}{l}\text { No abnormality } \\
(\text { No }(\%) \text { ) }\end{array}$ & $\begin{array}{l}\text { Abnormality } \\
(\text { No }(\%))\end{array}$ & $\begin{array}{l}\text { No abnormality } \\
\text { (No (\%)) }\end{array}$ & $\begin{array}{l}\text { Abnormality } \\
(\text { No }(1 /()))\end{array}$ \\
\hline \multicolumn{6}{|c|}{ Time from first employment $(y)$ : } \\
\hline$<10$ & 12 & $10(83)$ & $2(17)$ & $10(83)$ & $2(17)$ \\
\hline $10-19 \cdot 9$ & 41 & $29(72)$ & $11(28)$ & $27(73)$ & $10(27)$ \\
\hline $20-29 \cdot 9$ & 248 & $135(55)$ & $110(45)$ & $142(58)$ & $102(42)$ \\
\hline$\geqslant 30$ & 85 & $40(48)$ & $44(52)$ & $37(46)$ & $43(54)$ \\
\hline
\end{tabular}

*Total number of films available 'first film irrespective of time since first employment).

$\uparrow$ Number judged readable.

Table 9 Progression and attacks, $\geqslant 20$ years after last employment, by reader

\begin{tabular}{|c|c|c|}
\hline & $\begin{array}{l}\text { Reader } 1 \\
(n=212)^{\star} \\
(N o,(1))\end{array}$ & $\begin{array}{l}\text { Reader } 2 \\
(n=211) \star \\
(N o, \%)\end{array}$ \\
\hline $\begin{array}{l}\text { Parenchymal: } \\
\text { Cases with progression }{ }^{\dagger} \\
\text { Attacks }\end{array}$ & $\begin{array}{l}44(21) \\
21(10)\end{array}$ & $\begin{array}{c}29(14) \\
9(4)\end{array}$ \\
\hline $\begin{array}{l}\text { Pleural: } \\
\text { Cases with progression }+ \\
\text { Attacks }\end{array}$ & $\begin{array}{r}107(50) \\
44(21)\end{array}$ & $\begin{array}{l}77(36) \\
31(15)\end{array}$ \\
\hline
\end{tabular}

*Number of serial sets available and readable.

$\therefore$ Includes attacks.

over months in most cases rather than years. Of further interest is that exposure was almost exclusively to amosite.

Some of the parenchymal and pleural abnormalities may be attributable to exposures outside this work place, always a possibility in studies of industrial workers observed over decades. Occupational histories were taken, however, at the time of surveillance and those who admitted to asbestos exposure in other jobs ( 28 out of 414 with films available) were excluded from this study. Some of the others may have had unreported or unknown ex- posure to asbestos, either before or after surveillance commenced. This would result in overestimates of the rates of abnormality attributable to work in this factory. Unreported exposures could not, however, account for the dose-response relations found in this study.

Overreading could also account for some of the abnormality, particularly at the lower end of the ILO scale. Some of this was controlled for by adopting a more stringent definition of parenchymal abnormality-namely, a positive ILO reading by both readers. This lowered the prevalences and steepened the exposure-response curves compared with the findings for each reader individually. As there was no unexposed stratum in this workforce, the finding of a positive response in the lowest exposure stratum (around $10 \%$ using the stricter definition) remains consistent with an effect of brief intense exposure to amosite fibre.

Exposure at work was augmented by exposure at home. Among other household members resident during the employment period of the index worker, radiological abnormalities (small opacities or pleural abnormality) have been detected in $35 \%$ of those surveyed between 1973 and $1978 .^{5}$ Also, five cases of mesothelioma have been detected in these household 
contacts. Household members resident only after the period of employment showed no increase in small opacities and only a small increase in pleural thickening over that of a control population. ${ }^{5}$ The cumulative exposure of workers in this study therefore includes both occupational and domestic dust experience.

Some conclusions of clinical and epidemiological interest can be drawn from a study of this group. We have shown that radiological abnormalities indicative of interstitial pulmonary fibrosis and pleural thickening can develop with as little as one month's exposure to high concentrations of amosite fibre. We cannot determine when these changes first appeared, as surveillance began for the most part 20 or more years after these men had started (and in most cases left) employment.

Severe asbestosis after relatively brief exposure, of the order of a year or two, was described by Merewether in 1933. ${ }^{7}$ There have been few documented cases, however. Roggli et al ${ }^{\beta}$ evaluated lung tissue from six workers exposed to amosite in a plant in Tyler, Texas, similar to the plant described in this study. One of their cases had worked for two and a half weeks, and came to autopsy 21 years later having died of carcinoma of the lung. Moderate interstitial fibrosis was determined histologically, with a mean count of ferruginous bodies/g lung tissue of greater than 10000 . The chest radiograph showed evidence of interstitial fibrosis. Two other cases of lung cancer with a long time from employment (21 years) but a duration of exposure of only five weeks and two and a half months respectively, were found in the same study to have interstitial fibrosis histologically although not radiologically. Gaensler and Goff' reported severe asbestosis, histologically confirmed, in a worker who had spent only nine months in a cigarette factory working with crocidolite.

Our results are also pertinent to the question of a cumulative exposure threshold (although not to a concentration threshold, as concentration was high to extremely high by today's standards). Among these workers, no cumulative exposure threshold could be detected below which no parenchymal nor pleural abnormality occurred. Cumulative exposure levels producing low or negligible rates of interstitial fibrosis (determined radiologically or clinically) have been estimated in some studies, and range from 10 to 200 fibre-years $/ \mathrm{ml}^{10-12}$ Comparisons with other studies may not be possible, however, because of differences in industrial process and fibre characteristics, as well as the usual uncertainties surrounding dust counts. A notable feature that further distinguishes our group from those of the mentioned studies is the high concentration and short duration that characterised cumulative exposure. In this respect our cohort is similar to the crocidolite miners and millers studied by Cookson et al ${ }^{13}$ (mean duration of employment four months) among whom no threshold for asbestosis was found. It is possible therefore, that under certain circumstances, a high dose of fibre inhaled in a short period of time is more potent than the same cumulative exposure inhaled over a longer interval. This may be explained by high concentrations of inhaled fibre overwhelming the lung's defence mechanism or by the longer time available for the retained dose to act biologically in those who accumulate their dose rapidly.

Because of the brief exposures in this workforce, the usually strong correlation between cumulative exposure and time from first employment was weak. Time from first exposure could thus be examined independently of cumulative exposure. Although time from first employment has previously been shown to have a strong influence on parenchymal abnormality, we were unable to find this relation in our data. This is probably explained by the limited distribution of the variable within this study group; a high proportion of the group (221 out of 386) clustered within the stratum with 25 to 30 years from first employment.

By contrast, pleural abnormality showed a clear exposure-response relation with time from first employment. In stepwise multivariate analysis, this was the only predictor of pleural abnormality to remain in the model. The clarity of this relation despite the limited spread of time from first exposure in this study underscores the potent influence of time from onset of exposure, as distinct from cumulative exposure, in the appearance of pleural abnormality on the chest radiograph.

A recent review has concluded that among studies using the ILO standards for reading, cigarette smoking increases the prevalence of small opacities consistent with pneumoconiosis among asbestos exposed workers. ${ }^{14}$ In a previous study of asbestos insulation workers by our group ${ }^{15}$ smoking workers were found to have higher rates of parenchymal abnormality than non-smokers at all intervals from first exposure. In the present study, workers who had ever smoked had an overall rate of parenchymal abnormality 25 to $35 \%$ higher than that of non-smokers, depending on reader. This effect was detectable at almost all levels of cumulative exposure for both readers. Once the effect of cumulative exposure was controlled in multivariate analysis, however, smoking state could not be shown to have a further independent effect on the prevalence of parenchymal abnormality. Smoking state showed no influence on pleural abnormality in any of the analyses.

No standardised method exists for reading progression. We used direct progression scoring of side by side films in known temporal order rather than reading single films in random order according to the ILO scale. Our limited objective was to determine 
the prevalence of progression. The side by side method has been found to be at least as reliable as other methods and is of course logistically easier. ${ }^{1617}$ When compared with random order reading of single films on the ILO scale, direct progression scoring may, however, produce less regression and less progression of small opacities, and more progression of pleural thickening. ${ }^{18}$ In the side by side protocol used here, the readers were required firstly to score the films using the ILO scale. The use of a progression scale, however, allowed the reader to take technical factors into account and to overcome some of the limitations of the ILO scale. In some cases, progression may be evident over two films even though they merit the same ILO reading. This is particularly the case with pleural change. Conversely, the reader may apply a different ILO reading to a later film of a pair while believing that the difference in appearance is due to technical factors rather than to progression or regression of abnormality.

We have shown that progression of abnormalities on the chest $x$ ray film can occur after exposure has ceased. This has been shown in several studies. ${ }^{19-22}$ Of note in this group is that both first attacks and progression of established abnormality were evident 20 and more years after exposure had ceased. A similar finding regarding asbestosis was made by Cookson et al. among former crocidolite miners and millers. ${ }^{21}$ Interstitial pulmonary fibrosis and pleural thickening due to asbestos should thus be regarded as active processes irrespective of how much time has elapsed since exposure has ended.

Cumulative exposure was still a predictor of the likelihood of parenchymal progression even though exposure had ended two or more decades earlier. Age and smoking were not related to the likelihood of this "late" progression. The only predictor of pleural progression was time between first employment and the first film, and this only for reader 1 .

Although it is unlikely that exposures of the magnitude seen in this group would occur often today in industrialised countries, there is still alive a generation of asbestos workers who may have had comparable exposures in the 1950 s and 1960s. The long arm of early intense exposure continues to act on these workers. This had previously been shown for cancer. ${ }^{2}$ The short term exposures of these workers emphasise the need for clinicians to inquire carefully into brief remote exposures that may have been long forgotten. Furthermore, even in those with normal chest $x$ ray films two or more decades after ceasing exposure, radiological abnormality consistent with interstitial fibrosis or pleural thickening may yet appear.

We thank Jim Godbold PhD for his helpful advice regarding the statistical methods. The work was supported in part from NIH grant ROI-ES00928 and a grant from the Charles A Dana Foundation.

Requests for reprints to: Rodney Ehrlich, $\mathrm{MB}, \mathrm{ChB}$, Department of Community Health, University of Cape Town Medical School, Observatory 7925, Cape Town, South Africa.

1 Seidman H, Selikoff IJ, Hammond EC. Short-term asbestos work exposure and long-term observation. Ann NY Acad Sci 1979;330:61-90.

2 Seidman H, Selikoff IJ, Gelb SK. Mortality experience of amosite asbestos factory workers: dose-response relationships 5 to 40 years after onset of short-term work exposure. Am J Ind Med 1986;10:479-514.

3 Selikoff IJ, Seidman H, Hammond EC. Mortality effects of cigarette smoking among amosite asbestos factory workers. $J$ Natl Cancer Inst 1980;65:507-13.

4 Bader ME, Bader RA, Selikoff IJ. Pulmonary function in asbestosis of the lung: an alveolar-capillary block syndrome. Am J Med 1961;30:235-42.

5 Anderson HA, Lilis R, Daum SM, Selikoff IJ. Asbestosis among household contacts of asbestos factory workers. Ann NY Acad Sci 1979;330:387-400.

6 Fleiss JL. Statistical methods for rates and proportions. 2nd ed. New York: John Wiley and Sons, 1981;212-25.

7 Merewether ERA. A memorandum on asbestosis. Tubercle 1933;15:69.

8 Roggli VL, Greenberg SD, Seitzman LH, et al. Pulmonary fibrosis, carcinoma, and ferruginous body counts in amosite asbestos workers: a study of six cases. Am J Clin Pathol 1980;73:496-503.

9 Goff AM, Gaensler EA. Asbestosis following brief exposure in cigarette filter manufacture. Respiration 1972;29:83-93.

10 Weill H, Ziskind MM, Waggenspack C, Rossiter CE. Lung function consequences of dust exposure in asbestos cement manufacturing plants. Arch Environ Health 1975;30:88-97.

11 Berry G, Gilson JC, Holmes S, Lewinsohn H, Roach S. Asbestosis: a study of dose response relationships in an asbestos textile factory. $\mathrm{Br} J$ Ind Med 1979;36:98-112.

12 Finkelstein MM. Asbestosis in long-term employees of an Ontario asbestos-cement factory. Am Rev Respir Dis 1982; 125:496-501.

13 Cookson WOCM, De Klerk NH, Musk AW, et al. Prevalence of radiographic asbestosis in crocidolite miners and millers at Wittenoom, Western Australia. Br J Ind Med 1986;43:450-7.

14 Blanc PD, Gamsu G. Cigarette smoking and pneumoconiosis: structuring the debate. Am J Ind Med 1989;16:1-4.

15 Lilis R, Selikoff IJ, Lerman Y, Seidman H, Gelb SK. Asbestosis: interstitial pulmonary fibrosis and pleural fibrosis in a cohort of asbestos insulation workers: influence of cigarette smoking. Am J Ind Med 1986;10:459-70.

16 Liddell FDK, Morgan WKC. Methods of assessing serial films of the pneumoconioses: a review. J Soc Occup Med 1978;28:6-15.

17 De Klerk NH, Musk AW, James A, Glancy JJ, Cookson WOCM. Comparison of chest radiograph reading methods for assessing progress of pneumoconiosis over 10 years in Wittenoom crocidolite workers. $\mathrm{Br} J$ Ind Med 1990;47: 127-31.

18 McMillan GHC, Rossiter CE, Deacon R. Comparison of independent randomised reading of radiographs with direct progression scoring for assessing change in asbestos-related pulmonary and pleural lesions. Br J Ind Med 1982;39:60-1.

19 Becklake MR, Liddell FDK, Manfreda J, McDonald JC. Radiological changes after withdrawal from asbestos exposure. Br J Ind Med 1979;36:23-8.

20 Viallat JR, Boutin C, Pietri JF, Fondarai J. Late progression of radiographic changes in Canari chrysotile mine and mill exworkers. Arch Environ Health 1983;38:54-8.

21 Cookson W, De Klerk N, Musk WA, Glancy JJ, Armstrong B, Hobbs M. The natural history of asbestosis in former crocidolite workers at Wittenoom Gorge. Am Rev Respir Dis 1986;133:994-8.

22 Sluis-Cremer GK, Hnizdo E. Progression of irregular opacities in asbestos miners. Br J Ind Med 1989;46:846-52.

Accepted 12 August 1991 